\title{
Kerámia gömbhéjak mechanikai és mikroszerkezeti jellemzői
}

\section{Mechanical and Microstructural Features of Ceramic Hollow Spheres}

\author{
Kemény Alexandra, ${ }^{1,2, a}$ Károly Dóra ${ }^{1,2, b}$ \\ ${ }^{1}$ Budapesti Müszaki és Gazdaságtudományi Egyetem, Gépészmérnöki Kar, Anyagtudomány és Technológia \\ Tanszék, Budapest, Magyarország \\ ${ }^{2}$ MTA-BME Lendület Kompozit Fémhabok Kutatócsoport, Budapest, Magyarország \\ ${ }^{a}$ alexa@eik.bme.hu, ${ }^{b}$ kdora@eik.bme.hu
}

\begin{abstract}
In this study two different types of hollow sphere were examined by mechanical, geometrical and microstructural measurements, and the fracture force, geometrical properties and chemical composition were determined. The diameter of the „01 globocer” type specimens was $2.37 \mathrm{~mm}$ on average, while the value for the „03 globocer” type specimens was $6.88 \mathrm{~mm}$, both were smaller than the nominal diameter. The average deviation from the circularity of the 01 globocer specimens was $8 \%$, the value for the 03 globocer specimens was $6 \%$, while the average wall porosity was $53 \pm 3 \%$ and $56 \pm 3 \%$ respectively. The surface of the hollow spheres was uneven, which has an impact on the contact surfaces during pressure tests, which affects the fracture force values. The average value of the fracture force of 01 globocer spheres was $42 \mathrm{~N}$, and of 03 globocer hollow spheres was $288 \mathrm{~N}$. The diameter had a bigger impact on the fracture force values of the type 01 specimens than in the case of 03.
\end{abstract}

Keywords: ceramic hollow sphere, metal foam, mechanical properties.

\section{Összefoglalás}

Kutatásunk során két különböző gömbhéj mechanikai, geometriai és mikroszerkezeti vizsgálatát végeztük el a törőerő, geometriai tulajdonságok és anyagösszetétel meghatározása érdekében. A „01 globocer” típusú minták átmérője átlagosan 2,37 mm, a „03 globocer” típusú mintáké 6,88 mm, mindkettő kisebb a névleges méretnél, a körkörösségtől való eltérésük pedig rendre $8 \%$, illetve $6 \%$. A 01 globocer minták átlagos belső falporozitása $53 \pm 3 \%$, a 03 globocer mintáké $56 \pm 3 \%$. A gömbhéjak felülete egyenetlen, amely hatással van a nyomóterhelést átvevő felület méretére, így a törőerő-értékekre is, amelyek 01 globocer gömbhéjaknál $42 \mathrm{~N}$, a 03 globocer gömbhéjaknál pedig 288 N. A töréshez tartozó maximális erőértékek a 01 jelű gömbhéjaknál jobban függenek az átmérőtől, mint a 03 jelűeknél, előbbiben tendencia figyelhető meg.

Kulcsszavak: kerámia gömbhéj, fémhab, mechanikai tulajdonságok.

\section{Bevezetés}

Napjainkban az iparban elsődleges szerepet játszik a tömegcsökkentés megvalósítása az eredeti fajlagos mechanikai tulajdonságok megtartása vagy javítása mellett. A könnyű anyagokkal egyre inkább számoló anyagtervezési módszerek az energiahatékonyság mellett elérhető legjobb ár-érték arányra fókuszálnak. A szerkezet vagy berendezés terheléssel szembeni fajlagos ellenálló képességének növelése kisebb sűrűségű, nagyobb szilárdságú anyagok felhasználásával lehetséges, amelyhez a zárt cellás fémhabok adják az egyik legjobb megoldást. Leginkább járművek ütközőelemeiben használják energiaelnyelőként és szendvicspanelként [1]. 
A szintaktikus fémhabok (angolul metal matrix syntactic foams, MMSFs) olyan zárt cellás habok, amelyeknél a mátrix belsejében lévő pórusokat egy önmagában üreges fázis vagy töltőanyag képezi. A szakirodalomban többféle mátrix- és töltőanyagot vizsgálnak; az utóbbiak közül a leggyakoribb fajta a kerámia gömbhéj, amely anyaga lehet vegyes oxid [2,3], nagy tisztaságú $\mathrm{Al}_{2} \mathrm{O}_{3}[4$, 5] vagy $\mathrm{SiC}$ is [6, 7]. Ezek mellett használnak fémből készült gömbhéjakat [8] és habosított perlitet $[9,10]$ is töltőanyagként.

Az így gyártott szintaktikus fémhabok kiváló fajlagos energiaelnyelő képességgel és nyomószilárdsággal rendelkeznek, de az áruk viszonylag nagy [11].

A töltőanyagok tulajdonságai önmagukban kevéssé kutatott terület, pedig ezek is nagyban befolyásolják a belőlük gyártott fémhabok tulajdonságait. A vékony héjú gömbhéjak főként dinamikai terhelés hatására történő tönkremenetelét Dong és kutatócsoportja, valamint Ruan és kutatócsoportja vizsgálta. Mindkét csoport pingponglabdák nyomóvizsgálatát végezte a nyomószerszám geometriája, valamint az alakváltozási sebesség függvényében. Megfigyelték, hogy a terhelés sebessége nagymértékben befolyásolja a károsodás módját [12, 13].

Song és munkatársai fém gömbhéjak mikroszerkezetét és tönkremenetelét vizsgálták kísérleti úton és végeselemes modellel is. A gömbhéjak falában lévő eltérő eloszlású belső mikroporozitás hatására a tönkremenetel módja különbözik az egyes esetekben [14].

Mivel kevés szakirodalom áll rendelkezésre a témakörben, valamint a kutatócsoportok főként más alapanyagú gömbhéjak kifejezetten a zömítés során tapasztalt tulajdonságait vizsgálják, kutatásunk során célunk két gyakran használt kerámia gömbhéj geometriai, mikroszerkezeti és mechanikai jellemzőinek meghatározása volt.

\section{Eszközök és módszerek}

A kutatás során kétfajta kerámia gömbhéjat (1. ábra) vizsgáltunk a Hollomet gyártótól. Mindkét típusból 50-50 mintán vizsgáltuk a különböző mechanikai, geometriai és mikroszerkezeti tulajdonságokat.

A gömbhéjak névleges adatait - anyag, laza térfogatsűrüség és névleges átmérő - az 1. táblázat tartalmazza.

Először a minták átmérőjét mértük meg Mitutoyo Absolute Digimatic CD-15DC típusú tolómérővel, a mintákat forgatva a körkörösségtől való eltérés számszerűsítéséhez. Ezután a gömbhéjak törését végeztük el $0,1 \mathrm{~mm} / \mathrm{min}$ keresztfejsebességgel, két síklap között (2. ábra). A vizsgálatokat Instron 5965 típusú elektromechanikus, univerzális anyagvizsgáló berendezéssel végeztük.

Kétkomponensű epoxigyantába ágyazva a gömbhéjakat, a középvonalukig lecsiszoltuk, így vizsgálhatóvá vált a minták falvastagsága, belső szerkezete, falporozitása és köralakról való eltérése optikailag is Olympus SZX16 sztereo- és Olympus PMG-3 fémmikroszkóppal. A körkörösségtől való eltérést az (1) képlettel határoztuk

1. táblázat. A felhasznált gömbhéjak adatai

\begin{tabular}{|l|c|c|c|}
\hline & Alapanyag & $\begin{array}{c}\boldsymbol{\rho} \\
\left(\mathbf{g} / \mathbf{c m}^{3}\right)\end{array}$ & $\begin{array}{c}\emptyset D_{\mathbf{n}} \\
(\mathbf{m m})\end{array}$ \\
\hline 01 globocer & $\mathrm{Al}_{2} \mathrm{O}_{3} \mathrm{C} 795$ & 0,59 & 2,4 \\
\hline 03 globocer & $\mathrm{Al}_{2} \mathrm{O}_{3} \mathrm{C} 795$ & 0,60 & 7,0 \\
\hline
\end{tabular}

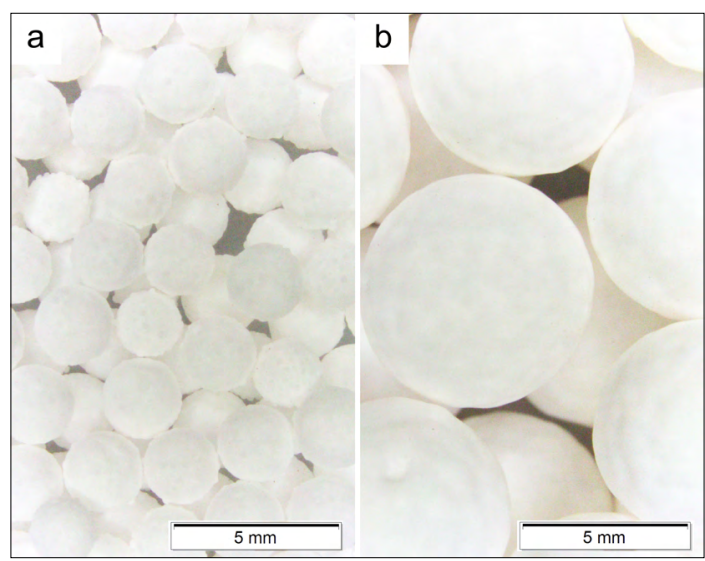

1. ábra. A felhasznált gömbhéjak képe: 01 globocer (a) és 03 globocer (b)

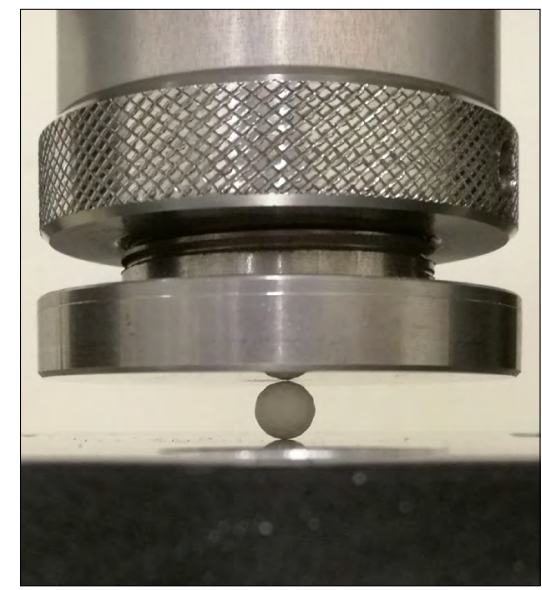

2. ábra. Mérési elrendezés a gömbhéjak töréséhez 
meg, ahol a legkisebb és legnagyobb mért értékek adták rendre a $D_{\min }$ és $D_{\max }$ értékeket.

$$
\frac{D_{\max }-D_{\min }}{\bar{D}} \cdot 100(\%)
$$

A morfológia további vizsgálatára Zeiss EVO MA10 típusú pásztázó elektronmikroszkópot (SEM) alkalmaztunk, az anyagösszetételt pedig a mikroszkóp EDAX típusú, energiadiszperzív röntgendetektorával határoztuk meg. A képeket $20 \mathrm{kV}$ gyorsítófeszültséggel, illetve szekunderelektrondetektorral készítettük.

\section{Eredmények}

A vizsgált gömbhéjak átmérőinek átlagértékét (øD) és szórását (s) a 2 . táblázat tartalmazza. Megfigyelhető, hogy a minták átlagosan a névleges méretnél kisebb méretűek.

A tolómérős átmérőmérésen felül a beágyazott és lecsiszolt mintákon is megvizsgáltuk a minták körkörösségét, valamint falvastagságát sztereomikroszkóppal. A mérések alapján elmondható, hogy a vizsgált minták metszete bár közelítően kör alakú, egyenetlen a gömbök felülete és falvastagsága is, ami így nagy hatással lehet a mechanikai tulajdonságaikra a terhelés irányától függően (3. ábra). A metszetek körkörösségtől való átlagos eltérése a 01 globocer mintánál 8\%, a 03 globocer mintánál pedig $6 \%$ volt.

A mikroszkóppal mért falvastagságok átlaga a 01 globocer esetén 0,125 mm, míg a 03 globocer esetén 0,346 mm. Az adatok segítségével kiszámolható az átlagos átmérőtényező, amely a vizsgált minták belső és külső átmérő hányadosainak átlagából adódik (3. táblázat).

Semleges gázzal végzett gáznyomásos, fémol-

2. táblázat. A vizsgált gömbhéjak átmérőértékei

\begin{tabular}{|l|c|c|}
\hline & 01 globocer & 03 globocer \\
\hline$\emptyset \overline{\mathrm{D}}(\mathrm{mm})$ & 2,37 & 6,88 \\
\hline$\emptyset \mathrm{D}_{\text {min }}(\mathrm{mm})$ & 2,00 & 6,44 \\
\hline$\emptyset \mathrm{D}_{\text {max }}(\mathrm{mm})$ & 2,65 & 7,36 \\
\hline $\mathrm{s}(\mathrm{mm})$ & 0,13 & 0,22 \\
\hline
\end{tabular}

3. táblázat. A vizsgált gömbhéjak átmérőaránya és elméleti porozitása

\begin{tabular}{|l|c|c|}
\hline & 01 globocer & 03 globocer \\
\hline$\varnothing \overline{\mathrm{d}}(\mathrm{mm})$ & 2,12 & 6,19 \\
\hline$\sum_{i=1}^{n} \frac{\varnothing \boldsymbol{d}_{i} / \varnothing \boldsymbol{D}_{i}}{n}$ & 0,90 & 0,90 \\
\hline $\mathrm{P}_{\mathrm{HAB}}(\%)$ & 55 & 58 \\
\hline
\end{tabular}

vadékos infiltrálást alapul véve, amely 64\%-os térkitöltést és homogén töltőanyag-eloszlást eredményez [15], kiszámolható a belső és külső átmérők aránya és egy elméleti porozitás $\left(\mathrm{P}_{\mathrm{HAB}}\right)$ a fémhabra [16, 17].

A felület egyenetlenségéről pontosabb képeket pásztázó elektronmikroszkóppal kaptunk (4. ábra). Mindkét típusú anyagnál elmondható, hogy egyenetlen a felületük, azonban a kisebb gömbök egyenetlenebbek a nagyobbaknál. A gömbhéjak külső és belső felülete is nagy felületi érdességgel rendelkezik a teljes méretükhöz viszonyítva.

A kerámia gömbhéjak falában lévő belső porozitás morfológiáját a csiszolatról készült fémmikroszkópos képeken (5. ábra), illetve a minták töretfelületén (6. ábra) is megfigyeltük.

Ezeken jól látszik, hogy bár ugyanabból az anyagból készültek a gömbhéjak, a kisebb átmérőjüben található pórusok nagyobbak, mint a nagyobb gömbhéjban találhatók, azonban összességében az arányuk kisebb (01 globocer-nél 53ะ3\% és 03 globocer-nál 56₫3\%).

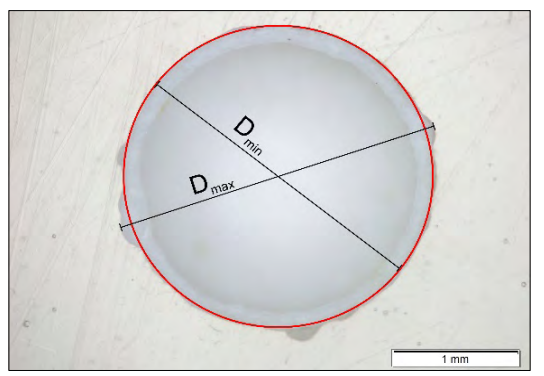

3. ábra. A 01 globocer gömbhéj metszeti képe

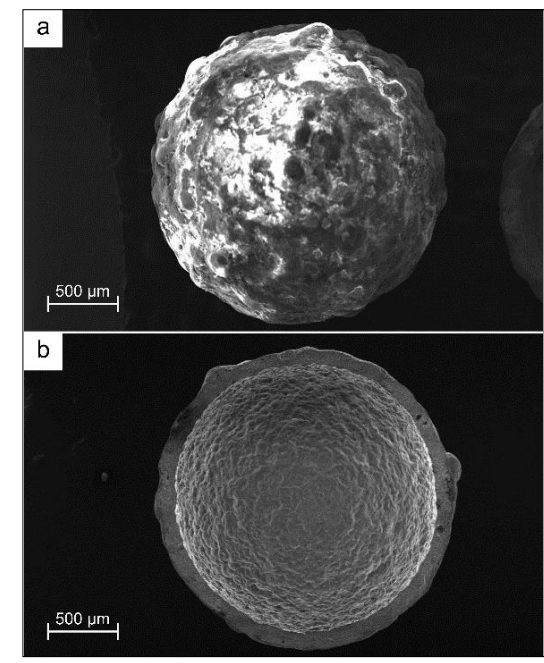

4. ábra. A 01 globocer gömbhéj külső (a) és belső (b) felületének SEM képe 


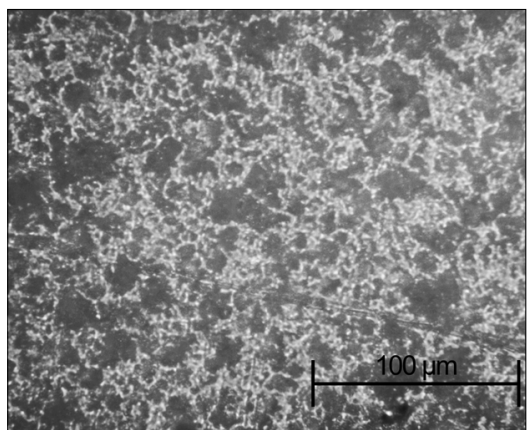

5. ábra. A 03 globocer falának fémmikroszkópos felvétele

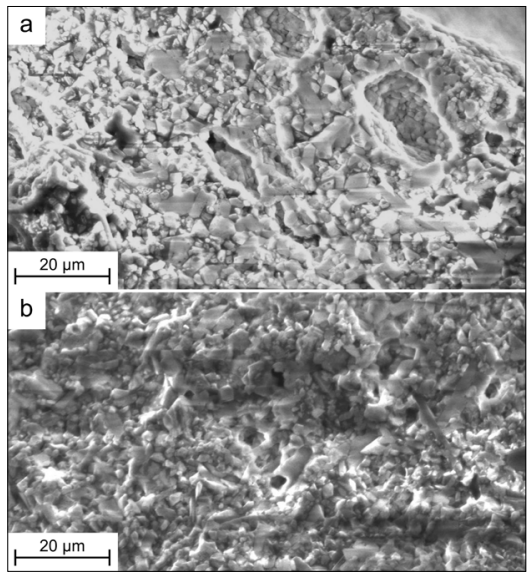

6. ábra. A 01 globocer (a) és a 03 globocer gömbhéj (b) falának töretfelülete

Ezen felül elmondható, hogy vízen történő úsztatáskor az ép gömbhéjak egy része nem úszik a felszínen. Ennek oka a fal nagymértékű porozitása.

A gömbhéjak mechanikai jellemzésére a törőerőt alkalmazzuk, mivel a gömbhéjak falvastagságának egyenetlenségei miatt nem kaptunk volna mérnökileg elfogadható szilárdsági értéket a fajlagosítással. A törőerő a zömítés során mért maximális erő.

A 7-8. ábra mutatja a kétféle gömbhéjon mért maximális erőértékeket az átmérőjük függvényében. Megfigyelhető, hogy a kisebb gömbhéjaknál az átmérő szórása befolyásolja a tönkremenetelhez tartozó erőértéket.

Az alumínium-oxid alapú kerámia gömbhéjak EDS-méréssel meghatározott anyagösszetételét a 4. táblázat tartalmazza. Az eredmények típusonként 3 különböző mintán lettek mérve a belső töretfelületeken, mintánként minimum 3 mérési pont átlagából lettek számítva.

Megfigyelhető, hogy a mérések során kapott átlagértékek 97-99\% mennyiségű alumíniumot és

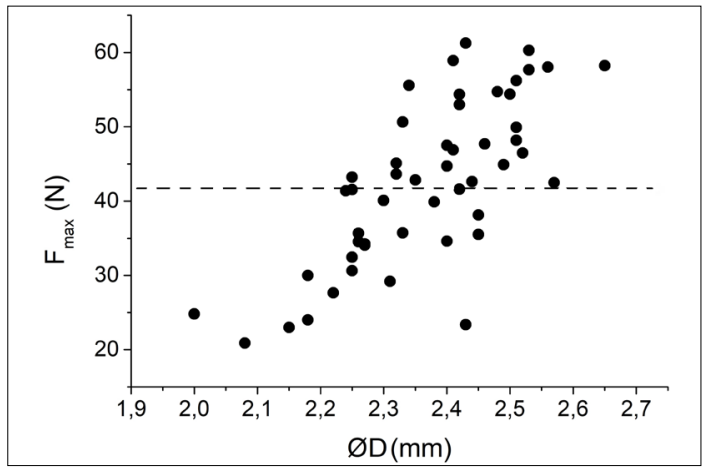

7. ábra. A 01 globocer gömbhéjak két síklap között végzett törésekor mért maximális erők az átmérö függvényében

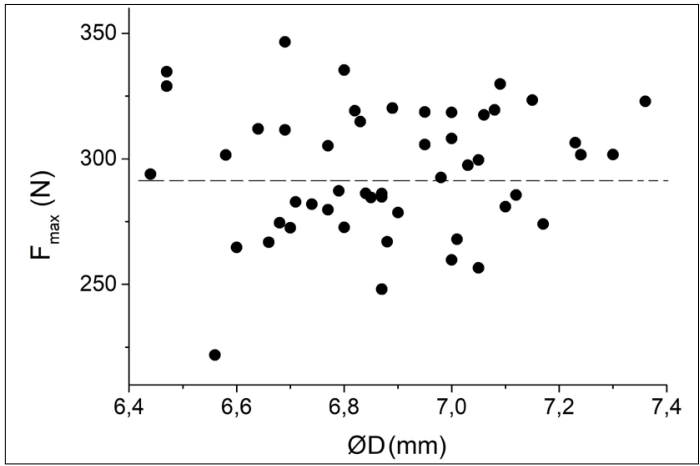

8. ábra. A 03 globocer gömbhéjak két síklap között végzett törésekor mért maximális erők az átmérö függvényében

4. táblázat. Vizsgált gömbhéjak anyagösszetétele

\begin{tabular}{|l|c|c|}
\hline & O (\%) & Al (\%) \\
\hline 01 globocer & $56 \pm 4$ & $42 \pm 3$ \\
\hline 03 globocer & $49 \pm 3$ & $50 \pm 5$ \\
\hline
\end{tabular}

oxigént mutatnak az anyagban, ezen kívül 1\% vagy annál kevesebb szilíciumot és kalciumot is tartalmazhatnak. Ez az érték összhangban van az MSZ EN 60672-3:1999 szabvány által előírt és a gyártó által megadott C795 anyagtípussal.

\section{Következtetések}

Összességében megállapítható, hogy a szintaktikus fémhabokban gyakran töltőanyagként alkalmazott kerámia gömbhéjak tulajdonságainak ismerete szükséges a mérnöki tervezéshez, így a mechanikai, geometriai és mikroszerkezeti tulajdonságok vizsgálata megalapozott. Kutatásunk során a következő megfigyeléseket tettük: 
- a 01 globocer minták átmérője átlagosan 2,37 mm, a 03 globocer mintáké 6,88 mm, mindkettő kisebb a névleges méretnél;

- a 01 globocer minták körkörösségtől való eltérése átlagosan $8 \%$, a 03 globocer mintáké 6\%;

- a gömbhéjak felülete egyenetlen, ami hatással van a nyomóterhelést átvevő felület méretére, így a törőerő-értékekre is;

- a 01 globocer minták átlagos belső falporozitása $53 \pm 3 \%$, a 03 globocer mintáké $56 \pm 3 \%$;

- a törőerő átlagos értéke 01 globocer gömbhéjaknál 42 N, szórása 12,5 N, 03 globocer gömbhéjaknál pedig $288 \mathrm{~N}$, szórása $41 \mathrm{~N}$;

- a töréshez tartozó maximális erőértékek a 01 jelü gömbhéjaknál jobban függnek az átmérőtől, mint a 03 jelüeknél;

- valamint mindkét típusú gömbhéj anyaga megfelel a gyártó által előírt anyagminőségnek.

\section{Köszönetnyilvánítás}

A kutatás publikálásában anyagi segítséget nyújtott a Gépészmérnök-képzésért Alapítvány. Ezúton is köszönjük a támogatást.

\section{Szakirodalmi hivatkozások}

[1] Gupta N., Rohatgi P. K.: 4.15 Metal Matrix Syntactic Foams. In: Comprehensive Composite Materials II. Elsevier, Oxford, 2018. 364-385. doi.org/10.1016/B978-0-12-803581-8.09971-9

[2] Szlancsik A., Katona B., Károly D., Orbulov I. N.: Notch (In)Sensitivity of Aluminum Matrix Syntactic Foams. Materials, 12/574. (2019) 15. doi.org/10.3390/ma12040574

[3] Zhang Q., Lee P. D., Singh R., Wu G., Lindley T. C.: Micro-CT characterization of structural features and deformation behavior of fly ash/aluminum syntactic foam. Acta Materialia 57. (2009) 3003-3011. doi.org/10.1016/j.actamat.2009.02.048

[4] Ferguson J. B., Santa Maria J. A., Schultz B. F., Rohatgi P. K.: $\mathrm{Al}_{-} \mathrm{Al}_{2} \mathrm{O}_{3}$ syntactic foams-Part II: Predicting mechanical properties of metal matrix syntactic foams reinforced with ceramic spheres. Materials Science and Engineering, A 582. (2013) 423-432. doi.org/10.1016/j.msea.2013.06.065

[5] Omar M. Y., Xiang C., Gupta N. Strbik, O. M., Cho K.: Data characterizing flexural properties of $\mathrm{Al}$ $\mathrm{Al}_{2} \mathrm{O}_{3}$ syntactic foam core metal matrix sandwich. Data Br, 5. (2015) 564-571. doi.org/10.1016/j.dib.2015.09.054

[6] Katona B., Szlancsik A., Tábi T., Orbulov I. N.: Compressive characteristics and low frequency damping of aluminium matrix syntactic foams. Materials Science and Engineering, 739. (2019) 140-148. doi.org/10.1016/j.msea.2018.10.014

[7] Cox J., Luong D. D., Shunmugasamy V. C., Gupta N., Strbik O. M., Cho K.: Dynamic and Thermal Prop- erties of Aluminum Alloy A356/Silicon Carbide Hollow Particle Syntactic Foams. Metals, 4. (2014) 530-548. doi.org/10.3390/met4040530

[8] Pérez L., Villalobos M., Órdenes C., Drew R. A. L., Ruiz-Aguilar C., Alfonso I.: Elastic Modulus Estimation for Copper Syntactic Foams Reinforced with Iron Hollow Spheres of Different Wall Thicknesses. Journal of Materials Engineering and Performance, 28/1. (2019) 100-106. doi.org/10.1007/s11665-018-3827-3

[9] Taherishargh M., Belova I. V., Murch G. E., Fiedler T.: The effect of particle shape on mechanical properties of perlite/metal syntactic foam. Journal of Alloys and Comppunds, 693. (2017) 55-60. doi.org/10.1016/j.jallcom.2016.09.168

[10] Fiedler T., Taherishargh M., Krstulovic-Opara L., Vesenjak M.: Dynamic compressive loading of expanded perlite/aluminum syntactic foam. Materials Science and Engineering, A, 626. (2015) 296-304. doi.org/10.1016/j.msea.2014.12.032

[11] Szlancsik A., Katona B., Orbulov I. N., Taherishargh M., Fiedler T.: Fatigue properties of EP/A356 aluminium matrix syntactic foams with different densities. IOP Conference Series: Materials Science and Engineering, 426. (2018) 8p. doi.org/10.1088/1757-899X/426/1/012045

[12] Dong X.L., Gao Z.Y., Yu T.X.: Dynamic crushing of thin-walled spheres: An experimental study. International Journal of Impact Engineering, 35/8. (2008) 717-726. doi.org/10.1016/j.ijimpeng.2007.11.004

[13] Ruan H. H., Gao Z. Y., Yu T. X.: Crushing of thinwalled spheres and sphere arrays. International Journal of Mechanical Science, 48/2. (2006) 117-133. doi.org/10.1016/j.ijmecsci.2005.08.006

[14] Song J., Sun Q., Luo S., Arwade S. R., Gerasimidis S., Guo Y., Zhang G.: Compression behavior of individual thin-walled metallic hollow spheres with patterned distributions of microporosity. Materials Science and Engineering A, 734. (2018) 453-475 doi.org/10.1016/j.msea.2018.08.016

[15] Finney J. L.: Random packings and the structure of simple liquids I. The geometry of random close packing. Royal Society of London A, 319/1539. (1970) 479-493. doi.org/10.1098/rspa.1970.0189

[16] Gupta N., Woldesenbet E., Mensah P.: Compression properties of syntactic foams: effect of cenosphere radius ratio and specimen aspect ratio. Composites Part A: Applied Science and Manufacturing, 35/1. (2004) 103-111. doi.org/10.1016/j.compositesa.2003.08.001

[17] Kiser M., He M. Y., Zok F. W.: The mechanical response of ceramic microballoon reinforced aluminum matrix composites under compressive loading. Acta Materialia, 47/9. (1999) 2685-2694. doi.org/10.1016/S1359-6454(99)00129-9 